\title{
ISSUES IN PUBLIC HEALTH
}

\section{COVID-19 and quarantine orders: A practical approach}

\author{
W M Botes, LLD; D W Thaldar, PhD \\ Health Law and Bioethics, School of Law, University of KwaZulu-Natal, Durban, South Africa
}

Corresponding author: W M Botes (botesm@ukzn.ac.za)

Quarantine is a very effective method for containing the spread of highly infectious diseases in large populations during a pandemic, but it is only effective if properly implemented. The co-operation and compliance of people entering quarantine are critical to its success. However, owing to the isolating and social distancing nature of quarantine, it often leads to extreme economic hardship and shortages in basic needs such as food, medicine, water and communication - and to the curtailment of certain universal social norms such as attending a parent's funeral. To escape these hardships, people often refuse to enter voluntary quarantine, or breach quarantine rules. In these circumstances, health authorities are obliged to act in the best interests of the public and obtain court orders to force some people into quarantine. In further extreme circumstances, when a national lockdown is ordered, non-compliance with quarantine measures may result in arrests and penalties. The scope of this article is limited to the period prior to and following such a lockdown, during which quarantine may still be vital for the containment of COVID-19. Because a quarantine order will deprive an individual of his or her freedom, this must be carefully balanced with the public interest. This article explains the legal and ethical considerations of this balancing exercise and provides practical guidance for obtaining quarantine orders.

S Afr Med J. Published online 22 April 2020. https://doi.org/10.7196/SAMJ.2020.v110i6.14794

Less than 48 hours after the South African (SA) government declared a national State of Disaster ${ }^{[1]}$ following the declaration of the World Health Organization (WHO) that the global COVID-19 outbreak had escalated to a pandemic, ${ }^{[2]}$ the Gauteng Department of Health was obligated to obtain a court order to force a mother and her daughter into isolation, after they tested positive for the COVID-19 virus and refused to voluntarily go into self-isolation. ${ }^{[3]}$

When the infection rate of the COVID-19 virus escalated dramatically, the SA government had declared a national State of Disaster in terms of section 27(1)(b) of the Disaster Management Act 57 of 2002 (DMA) ${ }^{[4]}$ and handed down guidelines in an effort to contain the spread of the pandemic virus. The anticipated success of both the regulations issued in terms of the National Health Act 61 of $2003^{[5]}$ (NHA) and the guidelines handed down in terms of the DMA is premised on social distancing, which includes the isolation of any infected person 'who is not critically ill but presents with mild symptoms ${ }^{36]}$ and quarantining persons exposed to the COVID-19 virus but who are not infected (hereinafter collectively referred to as 'quarantine'). However, considering the impact quarantine has on personal freedom and economic participation, people may refuse to subject themselves voluntarily to quarantine. ${ }^{[7,8]}$ In these circumstances, regulations issued in terms of the NHA provide measures in regulation 15(2) on how to obtain a court order that expressly limits a person's freedom ${ }^{[5]}$ and mandates his or her removal into quarantine..$^{[9]}$

\section{Regulations specific to the lockdown period}

When the pandemic worsened, South Africans were ordered into a national lockdown for 21 days from 26 March 2020, ${ }^{[10]}$ preceded by the issuing of the National Disaster Regulations (NDR) on 18 March $2020,{ }^{[11]}$ which are specifically applicable during the period within which a national State of Disaster is declared in respect of the COVID-19 pandemic. Regulation 4 of the NDR explicitly prohibits people to refuse consent to a medical examination, the taking of any bodily samples, admission to a health establishment or a quarantine site, or submission to mandatory prophylaxis, treatment or quarantine to prevent transmission of COVID-19. In the event of any non-compliance herewith, an enforcement officer can place the non-compliant person in quarantine for 48 hours, while the enforcement officer applies for a warrant, without the need to first obtain a court order to be issued by a magistrate for the medical examination of the non-compliant person. In this application, the enforcement officer must confirm under oath that the non-compliant person is confirmed as having been infected with COVID-19, is suspected of having contracted COVID-19, or has been in contact with or reasonably suspected of having been in contact with a person who is a carrier of or who is infected with COVID-19.

There is no vaccine against COVID-19, and despite the availability of vaccines against certain other viruses such as yellow fever, the latter virus and most other infectious viruses resurge on a regular basis. ${ }^{[12]}$ It is likely that there will be recurring COVID-19 outbreaks after the national State of Disaster has ended and the NDR have ceased to be in force. Quarantine measures contained in the NHA regulations not only precede but will also follow on the national State of Disaster.

\section{How to obtain a quarantine order}

Respiratory diseases caused by novel respiratory pathogens such as the influenza A virus, MERS coronavirus and now also the COVID19 virus are declared in regulation 12(1) of the NHA as category 1 notifiable medical conditions (NMCs) that require immediate reporting upon clinical or laboratory diagnosis to the National Department of Health $(\mathrm{NDoH})$ within 24 hours of diagnosis. However, healthcare providers who diagnose a patient with an NMC must report such medical conditions 'even before the case is laboratory confirmed. ${ }^{[5]}$ This legislative requirement is echoed in the standard operating procedures for the reporting of NMCs, compiled by the $\mathrm{NDoH}$ and the National Institute for Communicable 
Diseases (NICD), which similarly insist that category 1 NMCs 'must be notified based on clinical suspicion irrespective of laboratory confirmation. ${ }^{\text {'[13] }}$ Based on the contagious nature of category 1 NMCs, the motivation behind these reporting requirements is to enable authorities to mobilise a public health response, the success of which depends on the co-operation of all individuals affected by the public health interest - hence the need sometimes to force an individual to adhere to public interest decisions made during pandemics.

It must first be determined whether an individual is in fact obligated to subject himself or herself to a medical examination, testing, treatment or quarantine. The need for any of these invasive steps must be determined on a case-by-case basis, tailored depending on the health risk the individual may pose by coming into contact with other members of the public and the effect his or her personal circumstances may have on spreading the virus. If an individual who is a clinical or laboratory case, is a carrier of the COVID-19 virus or who has had contact with a carrier of the COVID-19 virus refuses to voluntarily subject himself or herself to a medical examination, the taking of any biological specimens, being admitted to a health establishment, or mandatory prophylaxis, treatment or quarantine in order to prevent transmission, the head of the provincial health department is obliged, in terms of regulation 15(2) of the Regulations Relating to the Surveillance and the Control of Notifiable Medical Conditions, issued in terms of the NHA, to apply to the relevant High Court for an 'appropriate' court order.

Once the 'appropriate' court order has been granted, the head of the provincial health department can, with the assistance of law enforcement agencies, physically subject a refusing individual to prophylaxis, treatment or the implementation of quarantine procedures. During the execution of these orders, it remains important to respect the individual's dignity and human rights, for failure may not only result in human rights infringements, but may also result in a public outcry, which, in turn may incite panic, protests and further breaches of quarantine. ${ }^{[14]}$

\section{Legal and ethical considerations}

To ensure that quarantine court orders are obtained and executed legally and ethically, the following must be considered in terms of the Constitution and the NHA and its regulations.

\section{Public health risk}

The NMC must demonstrate a real public health risk, objectively determined and based on scientifically obtained and credible information. The importance hereof relates to the fact that the effectiveness of any quarantine is closely related to the interval between exposure to the virus and the onset of the illness. Quarantine periods that are too long, as was the case with the Ebola quarantine in Liberia and the USA, can have devastating socioeconomic effects, ${ }^{[15,16]}$ while the relatively low rate of transmissibility of the causative coronavirus by asymptomatic individuals may lessen the need for and efficacy of large-scale quarantine. ${ }^{[17]}$ An individual's constitutional right to freedom cannot be limited by a quarantine order if such limitation is not based on the best available scientific evidence. COVID-19 is a category $1 \mathrm{NMC}$, the general nature of which is scientifically known to be very contagious, and it has quickly spread globally. ${ }^{[18]}$

\section{Refusal of voluntary measures}

During any disease outbreak of pandemic proportions, the very term 'pandemic' may often trigger panic among people, and it is not exclusively scientific considerations but also public response that are key to what the COVID-19 outbreak should be labelled as and how public healthcare strategy should be implemented. ${ }^{[19]}$ In these times people may fear for their own and others' lives and/or livelihoods, which may lead to people's refusal to subject themselves to testing or quarantine. $^{[20]}$

The wellbeing of a society as a whole relies heavily on the co-dependent relationship between that society and the individuals who comprise it. In addition to the sudden surge in medical emergencies resulting from the COVID-19 pandemic, which puts further pressure on the already overburdened SA healthcare system, balancing the rights of the individual with the need to protect the public becomes increasingly important and often complex. This balancing act may force health authorities to implement drastic measures to contain a disease or prevent it from spreading, which measures could conflict with people's human rights. ${ }^{[21]}$

In these circumstances, it is the poor, elderly, disabled, incarcerated and homeless who suffer the most. In Government of South Africa and Others $v$ Grootboom and Others ${ }^{[2]}$ the Constitutional Court held that sometimes the rights of individuals may be ranked above those of the collective, but this decision must be applied with care, as the socioeconomic circumstances of people in SA vary greatly.

The rights of people in the midst of an epidemic must be considered in both the textual setting of the SA Constitution ${ }^{[23]}$ and their socioeconomic setting. A person's right to health and healthcare consists of an intricately linked bundle of human rights that include the right to dignity, bodily and psychological integrity, privacy, an environment that is not harmful to health or wellbeing, emergency medical treatment and access to healthcare services, sufficient food, water and social security. The government's right to limit any of these constitutional rights during a pandemic by enforcing quarantine orders must be considered against its own constitutional obligation to take reasonable measures to achieve the realisation of these rights within available resources. Although the enactment of regulations relating to the surveillance and control of NMCs and reporting standard operating procedures are important first steps in the protection and realisation of these constitutional rights, these regulations must also be effectively implemented to ensure that the government complies with its constitutional obligations. For the implementation of these regulations to be respectful of human rights, they must be balanced between the rights of the individual and the collective. ${ }^{[14]}$ The closure of schools, the prohibition of public gatherings and business closures place serious burdens on society, which may contribute to people's refusal to self-quarantine or remain in quarantine.

To enforce quarantine, government must ensure sufficient access to resources to meet the basic needs of people whose movement and freedom will be restricted. ${ }^{[24]}$ During quarantine at home, people will need food, medicine and communication to enable health monitoring, including transportation of ill people to hospital. ${ }^{[21]}$ If the government cannot provide such basic needs, the forceful removal of any individual into quarantine will be unjustifiable and unethical.

The government is also obligated to ensure that its resources are applied to benefit its population holistically and are not to be prioritised for those who need healthcare resources the most, which issue was considered in Soobramoney $v$ Minister of Health (KwaZuluNatal) ${ }^{[25]}$ In this case, renal dialysis was refused to Mr Soobramoney, who was in urgent need of it, in order to rather benefit more patients who could actually be cured as a result of undergoing renal dialysis, as opposed to merely temporarily prolonging the life of a seriously ill person also suffering from various other illnesses. Despite the government's constitutional obligation to provide healthcare, food 


\section{Draft order}

Having heard counsel on behalf of the applicant, the following order is made:

1. that this application be adjudicated on an urgent basis and that the ordinary forms and time periods, otherwise provided for in the Uniform Rules, be dispensed with in terms of Uniform Rule 6(12)(a);

2. that the respondent is placed in quarantine, entailing that the respondent must stay at his/her home for 3 weeks commencing immediately;

3. that during this quarantine period the respondent may only leave his/her home:

3.1 in case of emergency, or

3.2 to obtain food and medicine;

4. that the name of the respondent may not be published in any way, including traditional/electronic media or word of mouth;

5. that a rule nisi be granted with a return date on [the next day] at 10h00, when the respondent must furnish reasons why the relief set out in prayers 2 and 3 above should not be confirmed and made final;

6. that the respondent may participate in the court proceedings on the return day via telephonic connection and need not be physically present in court himself/herself;

7. that the applicant or its representatives must reasonably attempt to call the respondent telephonically on [respondent's mobile telephone number] on the return date and time to establish a telephonic connection;

8. That [rank and name], the station commander of [nearest police station], is ordered to:

8.1 twice a day, send a patrol to the respondent's home to verify that the respondent is complying with prayers 2 and 3 of this order,

8.2 and file a brief report, on affidavit, every second day on the compliance of the respondent with prayers 2 and 3 of this order with the applicant at [applicant's attorney's e-mail address];

9. that the applicant's legal representatives must personally, and before $23 \mathrm{~h} 00$ on the date of this order, serve this order on the respondent and on the station commander and that such service will constitute proper service.

and water, the Constitutional Court, in Minister of Health $v$ Treatment Action Campaign, ${ }^{[26]}$ emphasised that this does not confer an entitlement to such claims and that the government is not obliged to deliver beyond available resources. Any public health response must thus be in proportion to the actual threat and not exclusively based on the outcome it may have on projected infection rates. ${ }^{[27]}$

\section{Consent}

Section 7(1)(c) of the NHA allows for health services to be provided without informed consent, on condition that this is authorised in terms of 'any law'. During a declared national State of Disaster, regulation 4 of the NDR, issued in terms of the DMA, will be the law that authorises medical examination, taking of any bodily samples, admission of any individuals to a health establishment or quarantine site, mandatory prophylaxis or treatment - without informed consent - to prevent transmission of COVID-19. The NHA further provides in section 7(1)(d) that health services may be provided to a patient if 'failure to treat the user, or group of people which includes the user, will result in a serious risk to public health', which treatment may broadly speaking include quarantine.

\section{A template quarantine draft order}

Regulation 15(2) of the Regulations Relating to the Surveillance and the Control of Notifiable Medical Conditions specifically allows for an 'appropriate court order. ${ }^{[5]}$ An 'appropriate' order is dependent on a balanced view of the best available scientific information, socioeconomic status, constitutional rights and public health considerations of each individual case as discussed above. In the insert above, we provide a template draft quarantine court order that can be adapted for specific circumstances.

Note that the template draft quarantine order provides that the respondent can 'appear' in court telephonically. This arrangement accommodates a potentially sick and infectious individual, while still complying with quarantine measures. Also, the no-publication order accords with regulations 18 and 19 that protect the individual's confidentiality with the view of shielding COVID-19-infected individuals from potential victimisation and stigmatisation.

\section{Conclusions}

The Greek physician Hippocrates wrote in his work Amorphisms that 'for extreme diseases, extreme methods of cure, as to restriction, are most suitable.' Quarantine is one such extreme method. Unfortunately, as in ancient Greece, economic hardships, social isolation, food rationing, water scarcity and sporadic communication are but a few of the consequences of quarantine. People may subsequently refuse voluntary quarantine, and health officials are then obligated to act in the best interests of public health and obtain court orders to force these people into quarantine. This article provides practical considerations for obtaining quarantine orders, which include the balancing of human rights with public health interests and concludes with a template court order.

\section{Declaration. None.}

Acknowledgements. The authors thank Adrian Bellengère and Magda Slabbert for helpful comments on this article. All remaining errors remain the authors' alone.

Author contributions. This article was co-authored, with equal contributions made by the authors.

Funding. University of KwaZulu-Natal, African Health Research Flagship Grant.

Conflicts of interest. None.

1. South African Government. Disaster Management Act: Declaration of a National State of Disaster: COVID-19 (coronavirus). https://www.gov.za/documents/disaster-management-act-declarationnational-state-disaster-covid-19-coronavirus-16-mar (accessed 16 April 2020).

2. World Health Organization. WHO Director-General's opening remarks at the media briefing on COVID-19 - 11 March 2020. https://www.who.int/dg/speeches/detail/who-director-general-sopening-remarks-at-the-media-briefing-on-covid-19---11-march-2020 (accessed 23 March 2020).

3. Ensore L. Police find family that refused quarantine for coronavirus. Business Day, 17 March 2020 https://www.businesslive.co.za/amp/bd/national/2020-03-17-police-find-family-that-refusedquarantine-for-coronavirus/ (accessed 18 March 2020).

4. South Africa. Disaster Management Act, 2002 (Act No. 57, 2002). Government Gazette No. 24252:98. 15 January 2003. http://www.cogta.gov.za/cgta_2016/wp-content/uploads/2016/06/DISASTERMANAGEMENT-ACT.pdf (accessed 16 April 2020).

5. South Africa. National Health Act of 2003. Regulations: Relating to the surveillance and the control of notifiable medical conditions. Government Gazette No. 41330:1434. 15 December 2017. https:// of notifiable medical conditions. Government Gazette No. 41330:1434. 15 December 2017. https://
www.nic.ac.za/wp-content/uploads/2017/12/41330_15-12_Health-compressed.pdf (accessed 16 April 2020). 
6. Official WhatsApp information service on the status of COVID-19 in South Africa from the National Department of Health. Last updated 20h00, 15 March 2020 https://www.sanews.gov.za/south-africa/ Department of Health. Last updated 20h00, 15 March 2020
access-all-covid-19-facts-whatsapp (accessed 16 April 2020).

7. Collman A. 5 million people left Wuhan before China quarantined the city to contain the coronavirus outbreak. Business Insider, 27 January 2020. https://www.businessinsider.com/5-million-left-wuhanoutbreak. Business Insider, 27 January 2020. https://WwW.businessinside
before-coronavirus-quarantine-2020-1?IR=T (accessed 18 March 2020).

8. Barbisch D, Koenig K, Shih F. Is there a case for quarantine? Perspectives from SARS to Ebola. Disaster Med Public Health Prep 2015;9(5):547-553. https://doi.org/10.1017/dmp.2015.38

9. Jobe KM. The constitutionality of quarantine and isolation orders in an Ebola epidemic and beyond. 51 Wake Forest L. Rev. 165 (2016). https://heinonline.org/HOL/LandingPage?handle=hein.journals/ wflr $51 \&$ div $=7 \&$ id $=\&$ page $=($ accessed 16 March 2020$)$.

10. Cotteril J. Ramaphosa orders 3-week lockdown for South Africa. Financial Times, 23 March 2020 https://www.ft.com/content/70243d64-6d3e-1 lea-89df-41bea055720b (accessed 25 March 2020).

11. South Africa. Disaster Management Act of 2002. Regulations issued in terms of section 27(2) of the Disaster Management Act, 2002. Government Gazette No. 43107:318. 18 March 2020. (Published under Government Gazette No. 318, 2020). https://www.saps.gov.za/newsroom/convid_regulations_2020. pdf (accessed 16 April 2020).

12. Tomori O. Yellow fever: The recurring plague. Crit Rev Clin Lab Sci 2008;41(4):391-427. https://doi. org $/ 10.1080 / 10408360490497474$

13. National Department of Health and National Institute of Communicable Diseases, South Africa. Standard Operating Procedures: Reporting of Notifiable Medical Conditions (NMC). Version: 2.0. Issue Date: January 2018. Paragraph 6. https://j9z5g3w2.stackpathcdn.com/wp-content/ 2.0. Issue Date: January 2018. Paragraph 6. https://j9z5g3w2.stackpathcdn.com/wp-content/
uploads/2017/06/SOP-Notifiable-Medical-Conditions_-notification-procedures_v2Jan2018finaluploads/2017/06/SOP-Notifiable-
Copy.pdf (accessed 16 April 2020).

14. Rothstein MA. From SARS to Ebola: Legal and ethical considerations for modern quarantine. Indiana Health Law Rev 2015;12(1):227-278. https://doi.org/10.18060/18963

15. Armour S, Lee CE. U.S. ebola response is slammed by lawmakers. Wall Street Journal, 17 October 2014 https://www.wsj.com/articles/u-s-ebola-response-to-be-examined-by-congress-thursday-1413459734 (accessed 16 April 2020)

16. Johnson K, Palmer J. Knock-on effects of China's coronavirus may be worse than thought. Foreign Policy, 3 February 2020. https://foreignpolicy.com/2020/02/03/knock-on-effects-china-coronavirusweak-economy-markets/ (accessed 19 March 2020).
17. Riley S, Fraser C, Donnelly CA, et al. Transmission dynamics of the ethiological agent of SARS in Hong-Kong: Impact of public health interventions. Science 2003;300(5627):1961-1966. https://doi. org/10.1126/science.1086478

18. Cascella M, Rajnik M, Cuomo A, et al. Features, evaluation and treatment of coronavirus (COVID-19). StatPearls Publishing, January 2020. https://www.ncbi.nlm.nih.gov/books/NBK554776/ (accessed StatPearls Publishing, January 2020. https://www.ncbi.nlm.nih.gov/books/NBK554776/ (accessed 20 March 2020)

19. Gilman SL. Moral panic and pandemics. Lancet 2010;375(9729):1866-1867. https://doi.org/10.1016/ S0140-6736(10)60862-8

20. Institute of Medicine (US) Forum on Microbial Threats. Ethical and legal considerations in mitigating pandemic disease: Workshop summary. 3: Strategies for Disease Containment. Washington, DC: National Academies Press, 2007. https://www.ncbi.nlm.nih.gov/books/NBK54163/ (accessed 16 April 2020).

21. McGorty EK, Devlin L, Tong R, Harrison N, Holmes M, Silberman P. Ethical guidelines for an influenza pandemic. NC Med J 2007;68(1):38-42. https://www.researchgate.net/profile/ Pam_Silberman/publication/6332546_Ethical_guidelines_for_an_influenza_pandemic/ links/00b7d52000f98c2391000000.pdf (accessed 18 March 2020).

22. Government of the Republic of South Africa and Others v Grootboom and Others 2001 (1) SA 46.

23. Constitution of the Republic of South Africa. Act No. 108 of 1996. https://www.gov.za/sites/default/ files/images/a108-96.pdf (accessed 16 April 2020).

24. World Health Organization. Global Influenza Programme. Whole-of-Society Pandemic Readiness. WHO guidelines for pandemic preparedness and response in the non-health sector. WHO, July 2009. https://www.who.int/influenza/preparedness/pandemic/2009-0808_wos_pandemic_readiness_final. pdf (accessed 16 April 2020)

25. Soobramoney v Minister of Health (KwaZulu-Natal) 1998 (1) SA 765 (CC).

26. Minister of Health v Treatment Action Campaign (No 2) 2002 (5) SA 271 (CC)

27. Parmet WE. J. S. Mill and the American law of quarantine. Public Health Ethics 2008;1(3):210-222. https://doi.org/10.1093/phe/phn029

Accepted 14 April 2020. 